Vol. 8, No. 2, 2021, 63-78

\title{
Media społecznościowe jako narzędzie aktywizacji osób starszych w okresie pandemii COVID-19. Analiza funkcjonowania na Facebooku organizacji wybranych z czterech polskich miast
}

\begin{abstract}
Streszczenie
Obostrzenia związane z pandemią COVID-19 ograniczyły funkcjonowanie całego społeczeństwa. Dla organizacji zajmujących się aktywizacją społeczną, np. osób starszych, oznaczało to wstrzymanie dotychczasowych działan. Czy możliwe było zatem dalsze aktywizowanie osób starszych? Celem badania jest zidentyfikowanie sposobów, w jaki wybrane organizacje w Polsce próbowały poradzić sobie z tą sytuacją za pośrednictwem swoich stron na portalu społecznościowym Facebook. Analizie poddano posty pochodzące z 20 kont prowadzonych przez organizacje zajmujące się aktywizacją społeczną osób starszych na terenie czterech miast wojewódzkich. W wyniku analizy tematycznej zebranych postów możliwe było określenie spectrum, w jakim funkcjonowały badane strony, tj. od kreatora rzeczywistości, dostarczającego najświeższych informacji do zażyłego znajomego, który troszczy się, pomaga, a nawet rozmawia ze swoimi odbiorcami. Z tym łączyła się również forma prowadzonej na stronach aktywizacji. Badania ujawniły różny stopień partycypacyjności działań prowadzonych przez organizacje, a przedstawione wnioski
\end{abstract}

1 Uniwersytet Ekonomiczny w Poznaniu, Instytut Społeczno-Ekonomiczny, halina.nadobnik@ue. poznan.pl, https://orcid.org/0000-0002-5155-9360 
stanowią wkład w badania nad mediami społecznościowymi w polityce publicznej oraz aktywizacją osób starszych.

Słowa kluczowe: pandemia COVID-19, Facebook, media społecznościowe, polityka senioralna, partycypacja

Kody klasyfikacji JEL: Z18, H84, L31

\title{
Social media as a tool for activation of older people during the COVID-19 pandemic: The analysis of the performance of selected organizations from four Polish cities on the Facebook platform
}

\begin{abstract}
The restrictions related to the COVID-19 pandemic limited the functioning of society as a whole. For organizations working in the field of social activation, e.g., for older people, this meant that existing activities came to a stop. Was it, therefore, possible to continue activating older people? The aim of this study is to identify the ways in which selected organizations in Poland tried to cope with this situation through their Facebook pages. Posts from 20 accounts run by entities involved in the social activation of older people in four provincial cities were analyzed. As a result of a thematic analysis of the collected posts, it was possible to determine the spectrum in which the examined pages functioned, i.e., from a creator of reality providing the latest information, to a close friend who cares for, helps, and even talks to the recipients. Also connected to this was the form of activation carried out on the sites. The research revealed varying degrees of participation in activities conducted by organizations and institutions, and the conclusions presented here are a contribution to research into social media in public policy and the activation of older people.
\end{abstract} Keywords: COVID-19 pandemic, Facebook, social media, senior policy, participation JEL Classification Codes: Z18, H84, L31

Pandemia COVID-19 i wprowadzane w związku z nią ograniczenia oddziaływały na wszystkich z nas, stopniowo redukując naszą decyzyjność w kwestii przemieszczania się, edukacji, aktywności zawodowej czy społeczno-kulturalnej. Szczególnie jednak na takie ograniczenia narażeni byli seniorzy, którzy ze względu na sugerowaną większą skłonność zarażenia się wirusem oraz mniejszą zdolność wyzdrowienia (Hoffman, Webster, Bynum, 2020) zachęcani byli do pozostania w domach. Położenie osób starszych wydaje się szczególne również dlatego, że ograniczenie ich aktywności mogło poskutkować pogorszeniem się ich sprawności oraz izolacją społeczną 
(Hoffman et al., 2020). Co za tym idzie przed dużym wyzwaniem stanęły organizacje zajmujące się aktywizacją osób starszych. Ich dotychczasowa działalność wymagała dostosowania do sytuacji ograniczenia kontaktów oraz okazji do wychodzenia z domu. Przestrzenią, do której przeniosło się życie społeczne, był Internet oraz wszelkiego rodzaju platformy społecznościowe. Jak pokazują badania, media społecznościowe okazują się istotnym nośnikiem informacji podczas katastrof naturalnych czy innych sytuacji krytycznych (Jayasekara, 2019). Jest to możliwe przede wszystkim dzięki dużej liczbie użytkowników Internetu, a także platform społecznościowych. W Polsce wg danych Eurostatu (2020) aż 80\% społeczeństwa korzysta z Internetu, odsetek ten zmniejsza się jednak w grupie wiekowej od 55 do 74 lat i wynosi 52\%. Stąd pojawia się pytanie, czy media społecznościowe były używane jako narzędzie do aktywizacji seniorów i w jaki sposób była ona realizowana w czasie pandemii. Celem artykułu jest analiza działań podejmowanych przez wybrane organizacje za pośrednictwem portalu społecznościowego Facebook.

$Z$ dotychczas przeprowadzonych badań wynika, że media społecznościowe mogą posłużyć jako narzędzie komunikacji między obywatelami a podmiotami publicznymi (Allcott, Braghieri, Eichmeyer, Gentzkow, 2020; Szmigiel-Rawska, Travares, 2019), np. miasta używają swoich kont na portalu społecznościowym Twitter do informowania, promowania, a nawet współrządzenia (Annusewicz, 2019). Wyniki przeprowadzonego badania umożliwiają rozszerzenie tej wiedzy o używanie mediów społecznościowych jako narzędzia aktywizacji społecznej, a co więcej pozwolą rozbudować rozumienie samego pojęcia aktywizacji o jego internetowy wymiar.

Analizę przeprowadzono na poziomie czterech polskich miast wojewódzkich, tj. Wrocławia, Krakowa, Łodzi oraz Poznania. Określenie zakresu analizy pokierowane było decentralizacją działań polityki senioralnej w Polsce. Proces ten polega na tworzeniu odgórnych założeń dla danej polityki, które następnie realizowane są na poziomie samorządu oraz miasta (Błędowski, Szweda-Lewandowska, 2016). Do badania włączono zatem organizacje działające na rzecz osób starszych na terenie badanych miast. Wybór organizacji podyktowany był ich suplementarnością wobec podmiotów państwowych w dostarczaniu usług mieszkańcom, a szczególnie osobom starszym.

\section{Media społecznościowe a polityka publiczna}

Za media społecznościowe uznawane są strony internetowe, które umożliwiają użytkownikom wymianę wiadomości oraz zamieszczanie treści widocznych dla poszczególnych osób, grup znajomych czy szerszych sieci społecznych (Brzozowska-Woś, 2013). Jedną z najbardziej znanych i używanych platform społecznościowych 
jest Facebook, który ma najwyższą liczbę użytkowników zarówno indywidualnych, jak i tych reprezentujących organizacje, firmy oraz podmioty publiczne na różnych szczeblach administracji (Statista, 2020). Facebook jako platforma społecznościowa daje możliwość umieszczania postów i zdjęć, udostępniania treści oraz ich komentowania. Dodatkowo może służyć jako narzędzie do tworzenia otwartych lub zamkniętych grup, w ramach których ich członkowie komunikują się ze sobą. Przykładem badania nad mediami społecznościowymi jest analiza postów przeprowadzona wśród grup dedykowanych młodym mamom. Jej celem była identyfikacja inicjatyw leżących u podstaw funkcjonowania studiowanych społeczności (Kaufmann, Buckner, 2014). Z kolei w badaniu dotyczącym grup dla osób doświadczających przemocy w sieci analizowano treści postów i rodzaj wsparcia udzielanego ofiarom przemocy (Alim, Khalid, 2019). Media społecznościowe, a w tym Facebook, stanowią obszerne pole badawcze umożliwiające obserwację sieci społecznych poprzez analizę sposobów komunikacji między jej użytkownikami oraz zawiązywania się poszczególnych w niej relacji (Jost et al., 2018; Kaufmann, Buckner, 2014).

Facebook - oprócz tego, że jest platformą dla indywidualnych użytkowników - stanowi również narzędzie komunikacji między przedsiębiorcami a klientami oraz podmiotami publicznymi, politykami a społeczeństwem. Platformy społecznościowe pozwalają stworzyć własną markę, nawiązać kontakt z konsumentami czy przekonać do siebie obywateli (Annusewicz, 2019; Appel, Grewal, Hadi, 2020; Goncalves, Liu, Xiao, Chaudhry, Hosio, 2015; Harrigan, Evers, Miles, Daly, 2017). Ponadto okazują się szczególnie przydatne, jeżeli chodzi o komunikację w obliczu katastrof $i$ innych niespodziewanych zdarzeń, m.in. jako narzędzie do rozpowszechniania informacji (Jayasekara, 2019; Landwehr, Carley, 2014; Palen, Hughes, 2018), ułatwiając komunikację z obywatelami w sytuacji klęski takiej jak pożar, huragan czy powódź, np. w 2016 r. na Sri Lance (Jayasekara, 2019). Co więcej, zauważa się coraz szersze użycie mediów społecznościowych przez władze krajowe czy regionalne do komunikowania się ze swoimi wyborcami, utrzymywania z nimi relacji czy nawet dostarczania im usług społecznych (Allcott et al., 2020; Annusewicz, 2019; Goncalves et al., 2015). Jako wirtualne przestrzenie są one dostępne dla szerokiego grona użytkowników i przez to są potencjalnym narzędziem do realizowania przez władze idei demokracji partycypacyjnej (Goncalves et al., 2015). Zwraca się uwagę na fakt, że nowe technologie, a w tym media społecznościowe takie jak Facebook, mogą pomóc we wzmacnianiu zaangażowania mieszkańców, dając im możliwość wyrażania swojej opinii i wpływania na tworzoną politykę. Również dostarczanie świadczeń dla mieszkańców może być łatwiejsze i poszerzone o ich własne zasoby, a ich wiedza i doświadczenia użyte do tworzenia społecznie innowacyjnych usług (Bertot, Jaeger, Munson, Glaisyer, 2010). 
W Polsce badania nad użyciem mediów społecznościowych przez władze miasta uwidoczniły jednak dosyć skromne ich wykorzystanie. W badaniach O. Annusewicza (2019) przeanalizowano oficjalne strony miast na portalu społecznościowym Twitter. Do badania włączono siedem polskich miast i tylko jedno z nich, Gdańsk, charakteryzowało się dwukierunkowym modelem komunikacji między władzami a mieszkańcami. Pozostałe miasta raczej używały swoich kont do informowania obserwatorów, nie wchodząc z nimi w relacje. Jak sugeruje Annusewicz (2019), konieczne jest zbadanie innych sposobów komunikowania się podmiotów publicznych z obywatelami.

\section{Osoby starsze w mediach społecznościowych}

Platformy społecznościowe tworzone były dotychczas głównie dla osób młodych, tzw. digital natives (Chou, Lai, Liu, 2012), jednak z badań wynika, że struktura użytkowników Internetu, jak i mediów społecznościowych, zmienia się, m.in. rośnie liczba użytkowników w wieku 55+. W rezultacie również osoby starsze zaczęły być postrzegane jako aktywni członkowie platform społecznościowych przez firmy, ale również przez organizacje dla nich działające (Klimczuk, 2018). Aktywność na portalach społecznościowych pozwala osobom starszym na utrzymywanie swojej dotychczasowej sieci społecznej, co może być trudniejsze ze względu na ich ograniczenia w poruszaniu się. Ponadto media społecznościowe pozwalają im na podtrzymywanie kontaktów z rodziną, mieszkającą często daleko od nich (Silva, Scortegagna, De Marchi, 2018). Z dotychczasowych badań wynika, że właśnie Facebook może być źródłem wsparcia, ale także narzędziem aktywizacji społecznej (Hoffman et al., 2020; Silva et al., 2018). Podkreśla się również istotną funkcję mediów społecznościowych w dostarczaniu usług społecznych dla osób starszych, z uwagi na fakt, że dają one możliwość tworzenia powiązań między konkretnymi organizacjami a osobami starszymi (Hoffman et al., 2020; Silva et al., 2018).

Biorąc pod uwagę potrzebę rozpoznania platform społecznościowych jako narzędzia komunikacji między obywatelami a władzami (Annusewicz, 2019; Munoz, Barbero, 2018; Szmigiel-Rawska, Travares, 2019) oraz podkreślany w badaniach potencjał w dostarczaniu przez nie usług społecznych (Goncalves et al., 2015), celem badania jest analiza sposobów komunikowania się wybranych organizacji działających na rzecz osób starszych na portalu społecznościowym Facebook w okresie pandemii COVID-19 oraz identyfikacja sposobów aktywizacji społecznej osób starszych za pomocą platformy Facebook. Wyniki badania stanowią wkład w wiedzę dotyczącą użytkowania portalu Facebook przez podmioty publiczne, a także pozwalają dowiedzieć się, jakie usługi dostarczano seniorom za pośrednictwem stron na Facebooku. 


\section{Metodologia}

Badanie zostało przeprowadzone z użyciem porównawczego studium przypadków (Rihoux, 2006). Metoda porównawcza daje możliwość dialogu pomiędzy poszczególnymi przypadkami, a przez to pełniejszej eksploracji badanego fenomenu. Skoncentrowanie się na miastach wiązało się z wyższym odsetkiem osób używających komputera oraz portali społecznościowych (GUS, 2019). Analizie poddane zostały zatem poszczególne organizacje z czterech polskich miast zajmujące się osobami starszymi. Wybrane zostały miasta wojewódzkie: Poznań, Kraków, Łódź oraz Wrocław. Dobór wynikał z ich zbliżonej charakterystyki administracyjnej oraz demograficznej (Rihoux, 2006). Wszystkie są stolicami województw o ludności liczącej między pięćset a siedemset tysięcy mieszkańców. Różni je jednak sposób, w jaki miasta oddelegowują działania pomocowe dla osób starszych. W dwóch z nich, tj. Poznaniu i Wrocławiu, powołano specjalne organizacje do działania na rzecz seniorów, natomiast w Krakowie i Łodzi zajmują się tym poszczególne wydziały urzędu miasta. Co więcej, w Poznaniu, Wrocławiu oraz Łodzi działają tzw. Kluby Seniora, czyli lokalne ośrodki aktywizacji osób starszych, z kolei w Krakowie podobną funkcję pełnią Centra Aktywizacji Seniora. Przedstawione różnice organizacyjne pozwalają na wewnętrzny dialog między materiałem empirycznym i lepsze zrozumienie badanego fenomenu (Rihoux, 2006).

\section{Zakres danych}

Dane zostały pozyskane przy użyciu skryptu facebook_scraper, pochodzącego ze strony GitHub (github.com, 2020), napisanego językiem programowania Python. W ten sposób możliwe było pobranie określonej liczby postów z poszczególnych kont na portalu Facebook. Następnie posty zostały zapisane w formie tekstowej i poddane analizie tematycznej (Alim, Khalid, 2019) przeprowadzonej za pomocą programu do analizy jakościowej Atlas.ti. W ramach czterech miast wyłonione zostały cztery organizacje, które prowadzą działalność na rzecz osób starszych i mają konto na portalu Facebook. Wybór podyktowany był popularnością stron wyznaczaną za pośrednictwem wyszukiwarki Google.pl. Procedura wyboru polegała na wpisywaniu ustalonej wcześniej frazy pozwalającej na wyszukanie najpopularniejszych stron na portalu Facebook: „senior/osoby starsze (nazwa miasta) facebok.pl/facebook.com”.

Znalezione strony zostały przejrzane pod kątem liczby obserwatorów i daty ostatnich postów. W pierwszej kolejności odrzucono strony, które nie zamieściły żadnych postów w 2020 r., w kolejnym mające mniej obserwatorów. Oprócz organizacji do 
analizy włączone zostały oficjalne profile miast. Celem było uwzględnienie kontekstu miasta, tego, co się w nim dzieje, i ewentualne zaobserwowanie, czy miało to wpływ na treści publikowane na poszczególnych stronach organizacji. W tabeli 1 znajdują się podmioty włączone do analizy. Zakres danych, tj. postów, został ograniczony do czterech miesięcy - od 1 stycznia do 30 kwietnia 2020 r., celem było uchwycenie momentu wybuchu pandemii i reakcji na nią.

Tabela 1. Organizacje poddane analizie na platformie Facebook

\begin{tabular}{|c|c|c|}
\hline Miasto & Nazwa organizacji & Identyfikator Facebook \\
\hline \multirow[t]{5}{*}{ Poznań } & Centrum Inicjatyw Senioralnych (podlegające UM Poznań) & @Centrumis \\
\hline & Miejska Rada Seniorów & @miejskaradaseniorowpoznan \\
\hline & Fundacja Młyn Wsparcia & @mlynwsparcia \\
\hline & Klub Seniora Górczyn & 257105634812971 \\
\hline & Miasto Poznań & @Poznan \\
\hline \multirow[t]{5}{*}{ Wroctaw } & Przestrzeń Trzeciego Wieku & 105793750800913 \\
\hline & Wrocławski Dzienny Dom Rozwoju Społecznego Senior+ & 1427424394047658 \\
\hline & Wrocławskie Centrum Seniora & @centrum.seniora \\
\hline & Klub Seniora na Psim Polu & @KlubSenioraNaPsimPolu \\
\hline & Miasto Wrocław & @wroclaw.wroclove \\
\hline \multirow[t]{5}{*}{ Łódź } & Seniorzy w Łodzi (w ramach Wydziału Miasta ds. polityki senioralnej) & SeniorzywLodzi \\
\hline & Klub Seniora Młodzi Duchem & @hipokampklub \\
\hline & Miasto Łódź & @lodzpl \\
\hline & Klub Seniora Cieszkowskiego & 336177440323583 \\
\hline & Fundacja System Aktywizacji Seniora & @systemaktywizacjiseniora \\
\hline \multirow[t]{5}{*}{ Kraków } & Centrum Aktywizacji Seniora Miechowity & @casmiechowity \\
\hline & Miasto Kraków & @wwwkrakowPL \\
\hline & Stowarzyszenie Radosny Senior & 205864366840514 \\
\hline & Szkoła@Aktywnego Seniora - S@S & @szkolaaktywnegoseniora \\
\hline & Centrum Aktywnego Seniora Złoty Wiek & @caszlotywiek \\
\hline
\end{tabular}

Źródło: opracowanie własne.

\section{Analiza}

Dane zostały przeanalizowane zgodnie z metodą analizy tematycznej. Jej użycie pozwoliło uporządkować zebrany materiał, a następnie zakodować oraz stworzyć wątki tematyczne odpowiadające na postawione pytanie (Nowell, Norris, White, Moules, 2017). Poniżej opisano pokrótce cztery etapy przeprowadzonej analizy:

1. Zapoznanie się z danymi - na tym etapie zapoznano się ze strukturą danych. Celem była identyfikacja pojawiających się znaczeń i charakterystycznych 
struktur, które mogą stanowić podstawę dla tworzenia kodów (Nowell, Norris, White, Moules, 2017).

2. Stworzenie wstępnych kodów - znając dane, stworzono kody na podstawie wcześniej określonych kategorii, wynikające z celów badania i literatury (Alim, Khalid, 2019; Annusewicz, 2019). W ramach tego etapu powstało finalnie 36 kodów, które pozwoliły na ustrukturyzowanie danych (Nowell et al., 2017).

3. Analiza danych oraz kodów pod kątem wyróżniających się wątków tematycznych - porównano uzyskane kody i połączono je w większe grupy, nazywane wątkami tematycznymi. Są to jednostki abstrakcyjne, które niosą w sobie jakieś konkretne znaczenia, istotne dla pytania badawczego (DeSantis, Ugarriza, 2000). W ten sposób kody, które jako takie nie niosą w sobie konkretnego wniosku, stworzyły wartościowe dla celu badania pojęcia teoretyczne (Braun, Clarke, 2006).

4. Powrót do danych i sprawdzenie wątków tematycznych - na tym etapie sprawdzono stworzone wątki tematyczne na podstawie wyodrębnionych za pomocą kodów fragmentów danych. Celem była weryfikacja włączenia poszczególnych kodów do wątków tematycznych poprzez analizę ich wzajemnej spójności. Każdy wątek sprawdzony został pod względem wystarczającej istotności, to jest znaczenia, które w sobie zawiera, oraz jego odniesienia do pytania badawczego (Nowell et al., 2017).

Wieloetapowe strukturyzowanie danych, a następnie ich interpretacja pozwoliły na rekonstrukcję badanego problemu wyłaniającego się z zebranych informacji. W ramach przeprowadzonej analizy uzyskano trzy wątki tematyczne, które opisują sposoby funkcjonowania stron podczas pandemii COVID-19, a także kwestię aktywizacji seniorów.

\section{Między zastrzykiem informacji a planowaniem czasu}

Funkcjonowanie prowadzonych przez badane podmioty stron na Facebooku można określić za pomocą całego spectrum ich aktywności - z jednej strony są konta udostępniające zwięzłe informacje odnośnie do podejmowanych działań, a z drugiej te zwracające się bezpośrednio do swoich odbiorców. Taka perspektywa pozwala uchwycić możliwe sposoby oddziaływania na obserwatorów, a także stopień zażyłości z nimi. W pewnym stopniu badane strony służyły do komunikowania rzeczywistości, ale również występowały w roli aktywnego agenta starającego się jednoczyć, aktywizować i wspierać. Poniżej opisano skrajne cechy wspomnianego spectrum, zawierające przykłady wpisów ze stron. 


\section{Komunikowanie rzeczywistości}

Odnosząc się do badań Annusewicza (2019), można zauważyć, że organizacje przyjmowały rolę „słupa z ogłoszeniami”, polegającą na używaniu swojej strony jako miejsca do publikowania ogłoszeń i udostępniania treści pochodzących z innych źródeł. Poniżej zamieszczone zostały przykłady takich postów ze strony Klubu Seniora Górczyn w Poznaniu. Trzy różne wpisy z kolejnych dni pojawiają się jako link odsyłający do strony Kolei Wielkopolskich, Miejskiej Rady Seniorów czy strony Sportsmamy, która oferuje treningi dla seniorów:

KOLEJE-WIELKOPOLSKIE.COM.PL

Oferta Specjalna: bilet miesięczny za złotówkę dla pracowników ochrony zdrowia. Koleje Wielkopolskie

2020-04-27 08:14:41

https://m.facebook.com/story.php?story_fbid=802268850296644iid=257105634812971

MRS.POZNAN.PL

Czy można odpoczywać na działce w rodzinnym ogrodzie działkowym? |

Miejska Rada Seniorów

2020-04-26 20:04:51

https://m.facebook.com/story.php?story_fbid=801968633659999iid=257105634812971

Sportsmama - Aleksandra Pierończyk

April 21 at 10:06 AM .

TRENING dla Seniorów 2

Pierwszy trening bardzo Wam się spodobał. Podrzucam drugi i mam nadzieję, że podeślecie linka swoim bliskim (Klub Seniora Górczyn w Poznaniu).

Taka forma prowadzenia strony dystansuje jej twórców od odbiorców, a brak interakcji, np. wchodzenia w dialog, ogranicza możliwości oddziaływania na czytelników. W okresie epidemii takie strony dostarczały po prostu najnowszych informacji związanych z nowymi ograniczeniami oraz komunikatami władz miasta i kraju. Przykładem innej formy informacji jest taka:

ODCZUWASZ SAMOTNOŚĆ?

CHCESZ POROZMAWIAĆ Z ŻYCZLIWĄ OSOBĄ BEZ WYCHODZENIA Z DOMU?

HALOFON DLA SENIORÓW (Seniorzy w Łodzi, WM Łódź).

Fragment dotyczy pomocy, jaką seniorzy mogli uzyskać w postaci rozmowy telefonicznej. W trakcie analizy można było zauważyć dużą popularność komunikatów informujących o numerach telefonów, pod którymi można z kimś porozmawiać. Tego typu posty były równie częste co te zawierające informacje dotyczące pomocy w robieniu zakupów, którą można było uzyskać od organizacji czy po prostu z miasta. 
Okazało się, że rozmowa z drugą osobą znalazła się wśród najważniejszych potrzeb osób starszych.

Przekazywanie informacji stanowiło jeden ze sposobów funkcjonowania badanych stron, które w różnej częstotliwości udostępniały swoim czytelnikom wiadomości oraz ciekawostki. W tych przypadkach media społecznościowe okazywały się raczej źródłem najnowszych informacji niż sposobem na komunikację i aktywizację.

\section{Stopień zażyłości}

Odwrotnością informacyjnego sposobu funkcjonowania stron było budowanie zażyłości między autorami strony a jej czytelnikami. Poniższy fragment stanowi przykład postów zamieszczanych przez Klub Seniora na Psim Polu we Wrocławiu i ilustruje bardziej bezpośredni sposób zwracania się do obserwatorów.

Kochani!

Tego, jak tęsknimy za spotkaniami z Wami, nie opiszą żadne słowa!

A sytuacja ta potrwa jeszcze długie tygodnie.

Szczerze wierzymy, że siedzicie w domu.

Dajcie nam informację zwrotną smsem, na messengerze, jak się macie, jak sobie radzicie.

Myślimy o Was (Klub Seniora na Psim Polu we Wrocławiu)

W ten sposób niektóre strony starały się budować bliższą relację z obserwatorami, a nawet nawiązywać rozmowę, zachęcając do pisania i dzielenia się swoimi przeżyciami. Interesujący jest również kierunek działania widoczny w powyższym poście. Osoby prowadzące klub seniora organizują aktywności dla osób starszych, natomiast oni są zachęcani, żeby przyjść, skorzystać i wziąć udział. Taki rodzaj działań dokonuje wyraźnego podziału na twórców i odbiorców, a co za tym idzie, ma mniej partycypacyjny, tj. angażujący, charakter. Kolejny fragment przedstawia jeszcze inną formę prowadzenia strony. W tym przypadku można odnieść wrażenie, że odbiorcy są równocześnie współtwórcami działań. Stąd posty polegają na relacjonowaniu wydarzeń z życia danej organizacji. W tej formie pisze np. Centrum Aktywizacji Seniora Miechowity w Krakowie. Posty są sprawozdaniem z tego, co dzieje się w Centrum, jakie są losy jego członków, a nawet jakie emocje towarzyszą tym spotkaniom.

Dzisiejsze spotkanie po intensywnych gimnastykach potrzebowaliśmy relaksu i rozluźnienia, toteż pyszna kawka i atmosfera pomogła nam w tym. Śpiewanie daje nam wiele przyjemności, a w dodatku żartobliwe piosenki, jakie dostarczył nam kolega Antoś, rozbawily nas kompletnie.

2020-01-20 21:17:55

https://m.facebook.com/story.php?story_fbid=1238204269703048iid=610279895828825

(CAS Miechowity Poznań) 
Jeszcze inny sposób budowania relacji z czytelnikami był widoczny po wybuchu pandemii, kiedy niektóre strony zachęcały do zaangażowanie się we wspólną akcję szycia maseczek:

Akcja szycia maseczek, z jaką wystąpił RKS oraz stowarzyszenie, spotkała się z ogromnym entuzjazmem. Nasze seniorki z zapałem rozpoczęły szycie tak deficytowego „towaru”, materiał został przekazany przez RKS oraz dwie panie, którym serdecznie dziękujemy. (Stowarzyszenie Radosny Senior w Krakowie)

Opisywaną zażyłość z czytelnikami można zrozumieć jako zakres partycypacji czytelników i członków organizacji, i ewolucje ich roli od odbiorców do współuczestników czy nawet współorganizatorów. Zamieszczone przykłady ilustrują tworzenie się idei partycypacji i koprodukcji wśród odbiorców, która polega m.in. na wspieraniu ich aktywności oraz ich zaangażowaniu (Olech, Kaźmierczak, 2011). Pokazuje to przejście od relacji bardziej podawczej do współodpowiedzialności i upodmiotowienia odbiorców usług poprzez zapraszanie do komunikowania się, wspólnych spotkań czy wzięcia udziału w jakiejś akcji, np. szycia maseczek.

\section{Aktywna dezaktywizacja}

Pandemia COVID-19 postawiła organizacje działające na rzecz seniorów w trudnej sytuacji, ograniczając ich dotychczasowe działania na rzecz społecznej aktywizacji osób starszych. Zgodnie z promowanymi koncepcjami starzenia się, tj. ideą aktywnego czy pomyślnego starzenia się, dobre samopoczucie oraz zdrowie fizyczne są tym lepsze, im dana osoba jest aktywniejsza zawodowo, fizycznie oraz społecznie (WHO, 2002). Szczególnie cele społecznej i fizycznej aktywizacji były widoczne w działaniach podejmowanych przez badane podmioty w miesiącach przed pandemią. Z kolei wraz z jej rozpoczęciem organizacje hamowały swoją działalność, a zamiast tego aktywnie promowały izolację jako sposób dbania o siebie. Wśród popularniejszych haseł znajdowały się: \#zostanwdomu; Nie ruszaj się z kanapy! lub Sztuka przyjdzie do ciebie! W rezultacie Internet stał się narzędziem do aktywnej dezaktywizacji. Okazało się, że przestrzeń publiczna jest dostępna online, w postaci wirtualnych spacerów lub relacji na żywo:

Zwiedzaj Wrocław, nie wychodząc z domu, wirtualne spacery z przewodnikiem.

Na wirtualny spacer po Wrocławiu można się wybrać za pośrednictwem transmisji live na fanpage VisitWroclaw (Przestrzeń Trzeciego Wieku we Wrocławiu)

Poniżej z kolei znajduje się zaproszenie do zwiedzania Muzeum Powstania Warszawskiego. 
Muzea też możemy zwiedzać bez wychodzenia z domu :-)!

Muzeum Powstania Warszawskiego

March 17 at 9:53 PM .

[WIRTUALNE MUZEUM POWSTANIA WARSZAWSKIEGO NA ŻYWO]

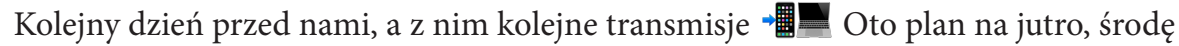
18.03 (Klub Seniora w Łodzi)

Jest to jedna $\mathrm{z}$ wielu propozycji muzeów w Polsce i na świecie, które oferowały wirtualne zwiedzanie. Oprócz tego pojawiały się możliwości wirtualnych spacerów po parkach narodowych, uczestnictwo w spektaklach online i wiele innych propozycji. Częstotliwość informowania o możliwych wydarzeniach czy transmisjach $\mathrm{w}$ miarę trwania pandemii intensyfikowała się, w rezultacie organizacje prowadzące strony pomagały osobom starszym w planowaniu dnia. Dobrze ilustruje to poniższy fragment ze strony Centrum Inicjatyw Senioralnych w Poznaniu, jednostki podlegającej Urzędowi Miasta:

PONIEDZIAŁEK:

9:00 - Zdrowy Kręgosłup - zoom

10:15 - Zdrowy Kręgosłup - zoom

11:30 - Zumba Gold - FACEBOOK GRUPA

17:00 - Zdrowy Kręgosłup - FACEBOOK

18:00 - Gimnastyka - FACEBOOK

(Centrum Inicjatyw Senioralnych w Poznaniu)

Zamieszczony rozkład dnia przedstawia możliwości skorzystania z zajęć online organizowanych przez Trenera Senioralnego. Skupienie się na aktywnościach, które może podjąć osoba starsza nie wychodząc z domu, pokazuje esencję działalności tego typu organizacji, które czy to online, czy w rzeczywistości pełnią funkcję organizatorów czasu seniorów. Nacisk na aktywność osób starszych jest elementem wspomnianych idei aktywnego i pomyślnego starzenia się (WHO, 2002). Oprócz proponowania aktywności, które można wykonać w domu za pośrednictwem Internetu, niektóre badane podmioty decydowały się na spotkania online, które miały zastąpić spotkania na żywo, dotyczyło to np. Klubu Seniora w Łodzi czy Centrum Aktywności Seniora Miechowity w Krakowie:

Tęsknimy za spotkaniami, a że musimy się zadowolić spotkaniem online, organizujemy więc kawiarenkę online, możemy się zobaczyć, porozmawiać, pożartować i od razu łatwiej znieść ten trudny czas. Zapraszamy do nas (CAS Miechowity w Krakowie).

W związku z tym nową umiejętnością, którą seniorzy zdobyli i wciąż zdobywają podczas pandemii, jest znajomość funkcjonowania w Internecie. Na stronach pojawiały się instruktaże, jak wziąć udział w poszczególnych transmisjach 
lub wydarzeniach online. Dodatkowo dostępna była pomoc wolontariuszy, którzy przez telefon tłumaczyli starszym osobom, jak skorzystać z niektórych funkcji na swoim telefonie czy komputerze. Przekierowanie działalności do sieci skupiło uwagę osób zajmujących się ludźmi starszymi na ich aktywność w Internecie i ich umiejętności technologiczne, a cyfrowa edukacja osób starszych zastąpiła ich społeczną aktywizację.

Zaprezentowane wyniki pokazują aktywną rolę badanych organizacji w powstrzymywaniu seniorów przed wychodzeniem $\mathrm{z}$ domu. Ukazują je również jako organizatorów czasu wolnego, który wypełniany jest różnymi aktywnościami. Dotychczas odpowiedzią na samotność seniorów było zachęcanie ich do wyjścia z domu, zaangażowania się i działania. Widać, że starano się zapewnić im to poprzez możliwość rozmowy, spotkania online oraz wypełniania czasu aktywnościami w sieci.

\section{$* * *$}

Wyniki przeprowadzonego badania pozwoliły zobaczyć spectrum, w jakim funkcjonują strony badanych organizacji. Odzwierciedla ono różne modele partycypacji. W przypadku postów komunikujących rzeczywistość możemy mówić o bardziej zdystansowanym i mało partycypacyjnym prowadzeniu działań przez daną organizację (Goncalves et al., 2015; Olech, Kaźmierczak, 2011). Z kolei posty odznaczające się zażyłą relacją z odbiorcami oznaczają próbę ich zaangażowania w prowadzone działania. Celowo te dwie cechy zostały określone jako granice całego spectrum funkcjonowania i co za tym idzie oddziaływania stron na obserwatorów, ponieważ cechowały się one mieszaną charakterystyką.

Ponadto warto zwrócić uwagę na nacisk, jaki organizacje kładły na jak najaktywniejsze spędzanie czasu. Jest to wciąż dominująca cecha polityki wobec osób starszych. Według Katza (2000) to właśnie aktywność jest ideą napędzającą działania polityki wobec osób starszych, wywodzącej się z idei produktywności w neoliberalnej gospodarce. Jak jednak wynika $\mathrm{z}$ jego badań, osoby starsze potrzebują nie tylko tego, aby wypełnić swój wolny czas aktywnościami, ale też dążą do znalezienia sensu w sposobach spędzania tego czasu.

Odnosząc się do badań nad przydatnością mediów społecznościowych w radzeniu sobie z sytuacjami kryzysowymi (Jayasekara, 2019; Vieweg, Hughes, Starbird, Palen, 2010), można zauważyć ich szerokie użycie przez badane organizacje, które starały się informować, ale także pomagać osobom starszym oraz angażować je poprzez swoje strony na Facebooku. Wydaje się, że sytuacja pandemii zmusiła również osoby starsze do aktywniejszego włączenia się w sieci społecznościowe. Jednak warte dalszych badań jest to, w jaki sposób używają one takich platform i jak się w nich odnajdują w porównaniu z użytkownikami zwanymi digital native (Chou et al., 2012). 
Przeprowadzone badanie obejmuje organizacje, które prowadzą działania na rzecz osób starszych. Analiza podmiotów z poszczególnych miast pokazała pewne zależności między nimi, które mogą być związane z ich suplementarnością (Błędowski, Szweda-Lewandowska, 2016; Szatur-Jaworska, 2016). Częste udostępnianie treści innych użytkowników, powtarzające się w ramach podmiotów z tych samych miast, może wskazywać na ich dobre usieciowienie, ale również pokrywającą się działalność.

Pewnym ograniczeniem badania jest różnorodność badanych podmiotów, która, choć konieczna ze względu na chęć porównania poszczególnych organizacji i instytucji dla uzyskania pełniejszego obrazu fenomenu, pomija bardzo różnorodny charakter podmiotów włączonych do analizy, mogący determinować ich sposób działania (Durczak, Ławrynowicz, Nadobnik, Sławecki, 2019).

\section{Bibliografia}

Alim, S., Khalid, S. (2019). Support for Cyberbullying Victims and Actors: A Content Analysis of Facebook Groups Fighting Against Cyberbullying. International Journal of Technoethics, 10(2): 35-56. DOI: 10.4018/IJT.2019070103

Allcott, H., Braghieri, L., Eichmeyer, S., Gentzkow, M. (2020). The Welfare Effects of Social Media. American Economic Review, 110(3): 629-676. DOI: 10.1257/aer.20190658

Annusewicz, O. (2019). Dialog obywatelski online a jakość polityki publicznej. Modele komunikacji administracji publicznej z obywatelami w mediach społecznościowych na przykładzie komunikacji prowadzonej na Twitterze przez wybrane polskie miasta. Studia $z$ Polityki Publicznej, 2(22): 89-102. DOI: 10.33119/kszpp/2019.2.4

Appel, G., Grewal, L., Hadi, R. (2020). The future of social media in marketing. Journal of the Academy of Marketing Science, 48: 79-95.

Bertot, J.C., Jaeger, P.T., Munson, S., Glaisyer, T. (2010). Social Media Technology and Government Transparency. Computer, 43(11): 53-59.

Błędowski, P., Szweda-Lewandowska, Z. (2016). Polityka wobec starości i starzenia się w Polsce w latach 2015-2035. Warszawa: Instytut Pracy i Spraw Socjalnych.

Braun, V., Clarke, F. (2006). Using thematic analysis in psychology. Qualitative Research in Psychology, 3: 77-101. DOI: 10.1191/1478088706qp063oa

Brzozowska-Woś, M. (2013). Media społecznościowe a wizerunek marki. Zarządzanie i Finanse, 11(1): 53-65.

Chou, W.H., Lai, Y., Liu, K. (2012). User requirements of social media for the elderly: a case study in Taiwan. Behaviour Information Technology, 32(9): 920-937. DOI: 10.1080/0144929X. 2012.681068

DeSantis, L., Ugarriza, D. (2000). The Concept of Theme as Used in Qualitative Nursing Research. Western Journal of Nursing Research, 22: 351-372. DOI: 10.1177/019394590002200308 
Durczak, K., Ławrynowicz, M., Nadobnik, H., Sławecki, B. (2019). Odkrywanie lokalnego Poznania. Poznań: Wydawnictwo Fundacji Naukowej Antypody.

Eurostat. (2020). Individuals - Internet use. https://ec.europa.eu/eurostat/databrowser/view/ isoc_ci_ifp_iu/default/table?lang=en (dostęp: 15.11.2020).

Github.com. (2020). Facebook Scraper. https://github.com/kevinzg/facebook-scraper/commit/ 924adf9cdfce6c7f24a748cbd8ae706661c14f2c\#diff-04c6e90faac2675aa89e2176d2eec 7d8R49 (dostęp 10.08.2020).

Goncalves, J., Liu, Y., Xiao, B., Chaudhry, S., Hosio, S. (2015). Increasing the Reach of Government Social Media: A Case Study in Modeling Government - Citizen Interaction on Facebook. Policy and Internet, 7(1): 80-102.

GUS (Główny Urząd Statystyczny) (2019). Społeczeństwo informacyjne w Polsce. Wyniki badań statystycznych z lat 2015-2019. https://stat.gov.pl/obszary-tematyczne/nauka-i-technika-spoleczenstwo-informacyjne/spoleczenstwo-informacyjne/spoleczenstwo-informacyjne-w-polsce-wyniki-badan-statystycznych-z-lat-2014-2018,1,12.html (dostęp: 15.11.2020).

Harrigan, P., Evers, U., Miles, M., Daly, T. (2017). Customer engagement with tourism social media brands. Tourism Management, 59: 597-609. DOI: 10.1016/j.tourman.2016.09.015

Hoffman, G.J., Webster, N.J., Bynum, J.P.W. (2020). A Framework for Aging-Friendly Services and Supports in the Age of COVID-19. Journal of Aging and Social Policy, 32(4-5): 1-10. DOI: $10.1080 / 08959420.2020 .1771239$

Jayasekara, P.K. (2019). Role of Facebook as a disaster communication media. International Journal of Emergency Services, 8(2): 191-204. DOI: 10.1108/IJES-04-2018-0024

Jost, J.T., Barber, P., Bonneau, R., Langer, M., Metzger, M., Sterling, J., Tucker, J.A. (2018). How Social Media Facilitates Political Protest: Information, Motivation, and Social Networks. Advances in Political Psychology, 39(3): 85-118. DOI: 10.1111/pops.12478

Katz, S. (2000). Busy Bodies: Activity, aging, and the management of everyday life. Journal of Aging Studies, 14(2): 135-152. DOI: 10.1016/S0890-4065(00) 80008-0

Kaufmann, R., Buckner, M.M. (2014). To connect or promote?: An exploratory examination of Facebook pages dedicated to moms. Computers in Human Behavior, 35: 479-482. DOI: $10.1016 /$ j.chb.2014.02.030

Klimczuk, A. (2018). Polityka publiczna wobec starzenia się ludności. Przegląd pojęć i podejść teoretycznych. Studia z Polityki Publicznej, 5(4): 67-94.

Landwehr, P.M., Carley, K.M. (2014). Social media in disaster relief. W: Data Mining and Knowledge Discovery for Big Data: 225-257. W.W. Chu (ed.). Berlin and Heidelberg: Springer.

Munoz, R.C., Barbero, F.L. (2018). Digital inclusion and active aging: the participation of the elderly in social networks. Aula Abietra, 47(1): 113-122.

Nowell, L.S., Norris, J.M., White, D.E., Moules, N.J. (2017). Thematic Analysis: Striving to Meet the Trustworthiness Criteria. International Journal of Qualitative Methods, 16(1): 1-13. DOI: $10.1177 / 1609406917733847$

Olech, A., Kaźmierczak, T. (2011). Modele partycypacji publicznej. W: A. Olech (red.), Partycypacja publiczna. O uczestnictwie obywateli w życiu wspólnoty lokalnej: 100-122. Warszawa: Instytut Spraw Publicznych. 
Palen, L., Hughes, A.L. (2018). Social Media in Disaster Communication. W: H. Rodríguez, W. Donner, J. Trainor (eds.), Handbook of Disaster Research: 497-518. Cham: Springer.

Rihoux, B. (2006). Qualitative Comparative Analysis (QCA) and Related Systematic Comparative Methods. International Sociology, 21(5): 679-706. DOI: 10.1177/0268580906067836

Silva, F., Scortegagna, S.A., De Marchi, A.C.B. (2018). Facebook as a Social Support environment for older adults. Universitas Psychologica, 17(3): 1-11. DOI: 10.11144/JAVERIANA. UPSY.17-3. FSSE

Statista (2020). Global social networks ranked by number of users 2020. https://www.statista.com/ statistics/272014/global-social-networks-ranked-by-number-of-users/ (dostęp 10.08.2020).

Szatur-Jaworska, B. (2016). Polityka społeczna wobec starzenia się ludności - konceptualizacja pojęć, ramy teoretyczne i aksjologiczne. W: Polska polityka społeczna wobec starzenia się ludności 1971-2013: 67-105. B. Szatur-Jaworska (red.). Warszawa: Dom Wydawniczy ELIPSA.

Szmigiel-Rawska, K., Travares, A.F. (2019). Rozważni czy romantyczni? Polscy wójtowie, burmistrzowie i prezydenci w mediach społecznościowych. Studia Regionalne i Lokalne, 20(77): 27-36.

Vieweg, S., Hughes, A.L., Starbird, K., Palen, L. (2010). Microblogging During Two Natural Hazards Events: What Twitter May Contribute to Situational Awareness. SIGCHI Conference on Human Factors in Computing Systems: 1079-1088. New York, NY: Association for Computing Machinery.

WHO (World Health Organization) (2002). Active Ageing: A Policy Framework: A contribution of the second United Nations World Assembly on Ageing. Geneva: WHO.

Unless stated otherwise, all the materials are available under 